\title{
Phyllopertha horticola (Coleoptera: Scarabaeidae) larvae in eastern Austrian mountainous grasslands and the associated damage risk related to soil, topography and management
}

\author{
Patrick Hann ${ }^{1,2^{*}}$, Claus Trska ${ }^{1}$, Katharina F Wechselberger ${ }^{1}$, Josef Eitzinger ${ }^{3}$ and Bernhard Kromp ${ }^{1}$
}

\begin{abstract}
The soil-dwelling larvae of several Scarabaeidae species (white grubs), like the cockchafer (Melolontha melolontha) and the garden chafer (Phyllopertha horticola), are serious pests in European cultivated grassland, reducing grass yield and destroying the turf by root-feeding. Nevertheless, the factors responsible for the development of large grub populations and the associated damage risk are poorly understood. The objectives of the study were to survey grub densities in grassland sites with different damage histories and find correlations with environmental and management variables. Data on grub densities were collected at 10 farms in the eastern Austrian Alps in September and October 2011. At each farm, one recently damaged site (high risk) and one site at which grub damage had never been observed by the farmers (undamaged site $=$ low risk; each site: $500 \mathrm{~m}^{2}$ ) were sampled. All sites were dominated by $P$. horticola ( $99 \%$ of 1,422 collected individuals; maximum density 303 grubs $/ \mathrm{m}^{2}$ ), which indicates that grub damage there is mainly caused by that species. Recently damaged sites tended to higher grub densities than undamaged sites. However, 3 out of 10 undamaged sites harbored high grub populations as well. Humus content together with the depth of the A-horizon significantly explained $38 \%$ of $P$. horticola grub density variance, with highest densities in deeper humus-rich soils. The risk of grub damage was positively connected to the humus content and negatively related to the cutting frequency. For the investigated mountainous grassland sites, these results suggest an important role of humus for the development of high grub densities and an effect of management intensity on grub damage.
\end{abstract}

Keywords: Phyllopertha horticola; Hoplia philanthus; Melolontha melolontha; Humus; White grubs; Cutting frequency

\section{Introduction}

White grubs, the soil-dwelling larvae of Scarabeidae species, cause severe damage to European cultivated grassland (Keller and Zimmermann 2005, Jackson and Klein 2006). Heavy grub feeding to the grass roots reduces the grass yield and can endanger farmers by causing their farm machines to slip down slopes on the detached sward. Based on a nationwide survey conducted in 2000, Strasser (2004a) forecasted increasing damage caused by Scarabaeidae larvae in several Austrian regions. In a survey, performed by interrogating plant protection consultants of 74 Agricultural

\footnotetext{
* Correspondence: p.hann@melesbio.at

${ }^{1}$ Bio Forschung Austria, Esslinger Hauptstrasse 132-134, Vienna 1220, Austria ${ }^{2}$ MELES GmbH, Mörikestraße 20, St. Pölten 3100, Austria

Full list of author information is available at the end of the article
}

County Chambers all over Austria, a cumulated area of 14,800 ha of white grub damage were recorded for the investigation period from 2000 to 2006 (Grünbacher et al. 2007, Hann et al. 2008).

According to the literature, the Scarabeidae (Coleoptera) species, mainly responsible for grub damage in Austrian alpine grasslands, are the cockchafers (Melolontha melolontha and M. hippocastani), the garden chafer (Phyllopertha horticola) and, to a lesser degree, the June beetle (Amphimallon solstitiale; Pötsch et al. 1997, Traugott 2003, Strasser 2004a, Keller and Zimmermann 2005). Keller (2004) reported A. solstitiale to cause damage mainly in sports turfs, parks and gardens. Also the survey results of Strasser (2004a) indicated that particularly M. melolontha and $P$. horticola cause increasing damage in 
cultivated grasslands all over Austria, while A. solstitiale is of lesser significance. Since the adults of $A$. solstitiale might be often mistaken for $M$. melolontha beetles, the contribution of this species to damage in managed pastures could as well be underestimated (Traugott and Juen 2008).

According to Pötsch et al. (1997), the areas damaged by the cockchafers are rather found in the valleys and plains of 300 to $600 \mathrm{~m}$ above sea level, while the areas damaged by the garden chafer extend from the valleys up into higher mountainous regions. This observation corresponds to Scheerpelz (1950), who stated that $M$. melolontha mainly occurs in areas with annual mean temperatures of at least $7^{\circ} \mathrm{C}$. Melolontha melolontha (adult: $20-30 \mathrm{~mm}$ ) has a three or four year life cycle in Austria, while the smaller $P$. horticola (adult: $8.5-12 \mathrm{~mm}$ ) completes its larval development within one year (Raw 1951, Freude et al. 1969, Pötsch et al. 1997). Due to its shorter life cycle, $P$. horticola can build up high population densities more quickly in response to favourable environmental conditions. Faber (1961) discovered a transition from a four-year to a three-year development cycle of $M$. melolontha, particularly in some Alpine valleys. This trend is probably connected to increasing mean temperatures (Keller 1993, Scheifinger et al. 2007). However, recent systematic grub density surveys in damaged Austrian grasslands are not reported in the literature.

Since the larvae of the problematic Scarabaeidae species are soil dwelling, their population densities and the associated damage risk are probably depending on site characteristics that influence soil temperature, soil moisture and resilience of the sward, like grain size, humus content or management impact on vegetation coverage. Although this hypothesis is supported by observations reported in the literature, the environmental conditions that are determining grub populations and the damage risk in grassland sites are poorly understood.

Zweigelt 1928 (quoted by Scheerpelz 1950) described climatic and soil conditions as main factors responsible for high densities of Melolontha ssp. grubs. Similarly, population fluctuations of $P$. horticola can be attributed to climatic factors (Milne 1964 and 1984). Laznik et al. (2012) stated that grubs are most common in sandy or sandy loam soils, but can also occur in clay soils. According to Scheerpelz (1950), Pötsch et al. (1997) and Albert and Fröschle (2010), for oviposition, M. melolontha prefers dry, loose soils and sunny meadows, particularly with a slightly gappy sward and a high temperature radiation which might direct the female beetles to suitable locations. Furthermore, for the optimal development of the larvae warm, dry, moderately permeable, deep and eutrophic soils are needed (Scheerpelz 1950). In contrast, Faber (1951a) stated that the locations with not too high, but closed vegetation are selected for oviposition. Similarly to M. melolontha, P. horticola prefers dry and sunny habitats with sandy soils and slightly gappy swards, while dense swards with high vegetation inhibits the egg deposition of the females (Milne 1964, Bocksch 2003). In British grassland sites, Raw (1951) observed a preference of $P$. horticola adults for dense, unscythed vegetation, but reports that more grubs of the species could be found in dry friable than in moist soils. Apart from a possible effect on egg deposition, a dense, well supplied sward reduces soil warming and might endure grub feeding to the roots much better than weak grass plants. Accordingly, management measures that support a dense sward, like a balanced cutting, grazing and manuring regime, are considered to reduce the risk of grub damage (Pötsch et al. 1997).

The control of Scarabaeidae larvae by means of chemical pesticides is quite difficult because of their cryptic habitat. Apart from problems with application into soil, there is growing concern about safety and environmental contamination linked to the usage of chemical pesticides (Jackson and Klein 2006). Approaches to organic grub control are the application of nematode and entomopathogenic fungi products, like Melocont ${ }^{\oplus}$ (Beauveria brongniartii) against $M$. melolontha grubs and GranMet-P ${ }^{\odot}$ (Metarhizium anisopliae) against $P$. horticola. After application, the fungus-epizootic needs time to spread in the soil (Strasser 2004b, Keller and Zimmermann 2005, Jackson and Klein 2006). A grub damage risk forecasting system based on site characteristics and climate would enable the farmers to take measures in time. However, the development of such a system requires better knowledge of the relationships between site, climate and management factors, grub densities and damage.

The main objective of our study was to investigate the factors that determine the risk of grub damage in mountainous agricultural grasslands. Therefore the relevant tasks were to i) survey grub densities in grassland sites to reveal the dominant species and find correlations with environmental and management variables and ii) to compare damaged and undamaged grassland sites to reveal site and management characteristics that increase the risk of grub damage.

\section{Materials and methods \\ Sampling sites}

We examined two sampling regions (Figure 1), which were affected by grub damage, over the last decade. Region 1 was situated in north-eastern Styria, covering the upper Feistritz valley (district Weiz) and the upper Lafnitz valley (district Hartberg). This region had a north-south extent of about $8 \mathrm{~km}$ and an east-west extent of about $14 \mathrm{~km}$ and contained 18 of the 20 sampling sites. The second sampling region (region 2) was situated about $90 \mathrm{~km}$ west of region 1 in central-western Styria (upper Mur valley, district Murtal). It contained only two sites with a distance of about $500 \mathrm{~m}$. 


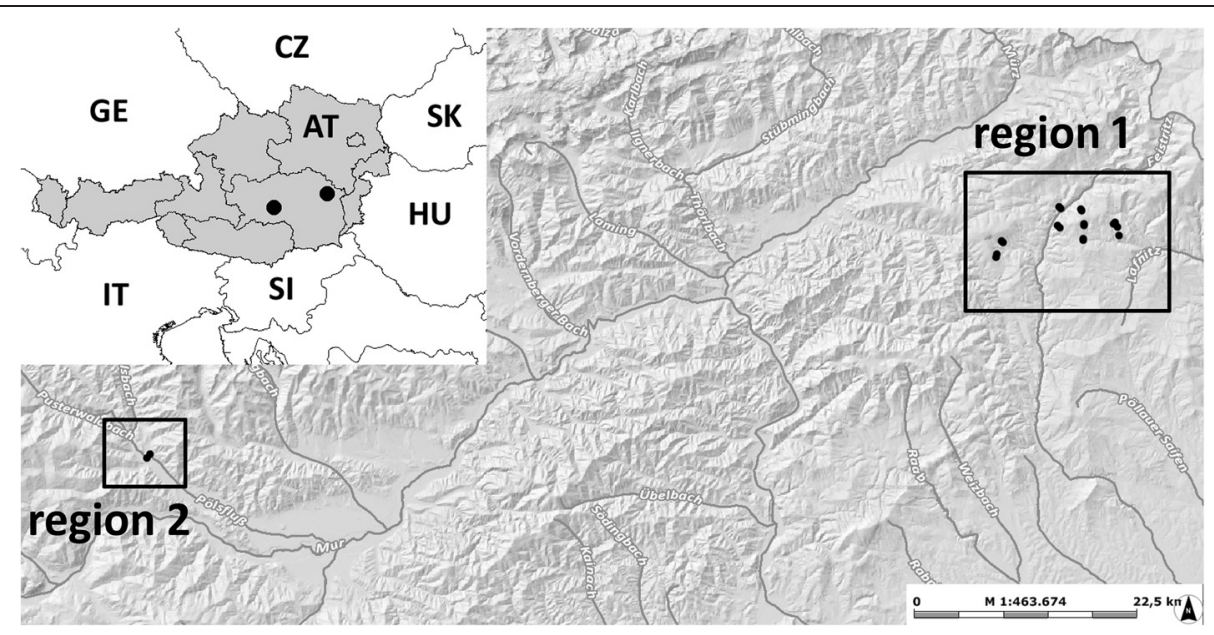

Figure 1 Situation of the grub sampling sites in eastern Austria. The sites are indicated by small black dots: region $1=$ south-eastern alpine foothills, region 2 = central-eastern alps. The small map in the upper left corner shows the situation of the sampling regions within Austria/Europe (large black dots); AT = Austria, CZ = Czech Republic, GE = Germany, HU = Hungary, IT = Italy, SI = Slovenia, SK= Slovakia (www.gis.steiermark.at).

Both regions were mountainous and dominated by agricultural grassland. The altitudes of the sampling sites varied between 839 and $1,104 \mathrm{~m}$ above sea level in region 1 and 898 and $906 \mathrm{~m}$ in region 2. The climatic characteristics of the regions are shown in Table 1 . The sites in both regions were characterized by sandy, limefree Leptosols or Cambisols over siliceous, gravelly material (eBOD, 2013).

The individual sampling sites were determined in two steps. First, we selected 10 farms which had recently reported grub damage (without knowing the grub species) and, in the case of region 1, were evenly distributed over the sampling region (Figure 1, Figure 2 and Table 2). At each farm, we asked for two sites: a grassland site which had recently been damaged by grubs (= damaged sites) and a second site at which grub damage had never been observed by the farmers (= undamaged sites; mean distance between the two sites: $315 \mathrm{~m}$; range: $180-836 \mathrm{~m}$ ). We postulated that: 1) The observations of farmers

Table 1 Climatic characteristics (1971 - 2000) of the two sampling regions, measured at representative weather stations (ZAMG 2014)

\begin{tabular}{lll}
\hline & Region 1 & Region 2 \\
\hline Weather station & Fischbach & Oberzeiring \\
Coordinates of the station & $47^{\circ} 27^{\prime} \mathrm{N}, 15^{\circ} 53^{\prime} \mathrm{E}$ & $47^{\circ} 15^{\prime} \mathrm{N}, 14^{\circ} 29^{\prime} \mathrm{E}$ \\
Altitude (m above sea level) & 1,050 & 930 \\
Situation of the station & North-eastern & Valley, southern \\
& slope & slope \\
Mean temperature $\left({ }^{\circ} \mathrm{C}\right)$ & 13.12 & 13.04 \\
$\begin{array}{l}\text { Mean precipitation sum per } \\
\text { month (mm) }\end{array}$ & 583.0 & 525.2 \\
\hline
\end{tabular}

The measured data were averaged across the adult flight and main larval feeding period (May - September) of Phyllopertha horticola (Scarabaeidae). regarding grub damage were highly reliable, because grub damage meant difficulties in management, economic loss and even danger, since machines can slide on a detached sward. 2) The risk of grub damage is higher at sites where grub damage had recently occurred (damaged sites $=$ high risk) than at sites at which damage had never been observed by the farmers (undamaged sites $=$ low risk). Our approach assured that the sampling sites met two important requirements for our study. Each site had a grub infestation potential, since grub damage had been reported recently, at least in its vicinity, and the sites covered two grub damage risk levels (low risk and high risk). This was important for investigating relationships between grub damage risk, environmental and management variables.

Each sampling site covered an area of $500 \mathrm{~m}^{2}$. For measuring grub density, 24 soil samples were taken evenly distributed across this area. These subsamples had an extent of $20 \times 20 \mathrm{~cm}$ and reached about $10 \mathrm{~cm}$ into the topsoil (A-horizon), since the common grub species in Middle European grasslands ( $M$. melolontha, P. horticola, A. solstitiale, Hoplia philanthus) are usually located not deeper than $10 \mathrm{~cm}$ during summer and autumn feeding (Raw 1951, Milne 1956, Hasler 1986, Keller 2004, Benker and Leuprecht 2005). The subsamples were cut out with a spade and searched on a tablet for grubs. All grubs were counted: all undamaged grubs were collected for determining the species (Klausnitzer 1996). The samplings were conducted from September $1^{\text {st }}$ until October $4^{\text {th }} 2011$. At this time, the grubs were feeding on the grass roots a few millimeters to centimeters beneath the soil surface. Thus, the grubs could easily be found (Figure 3).

In addition to estimating the grub densities, we also recorded current grub damage in 2011 (yes/no). In order to obtain material for soil chemical analyses, we took 


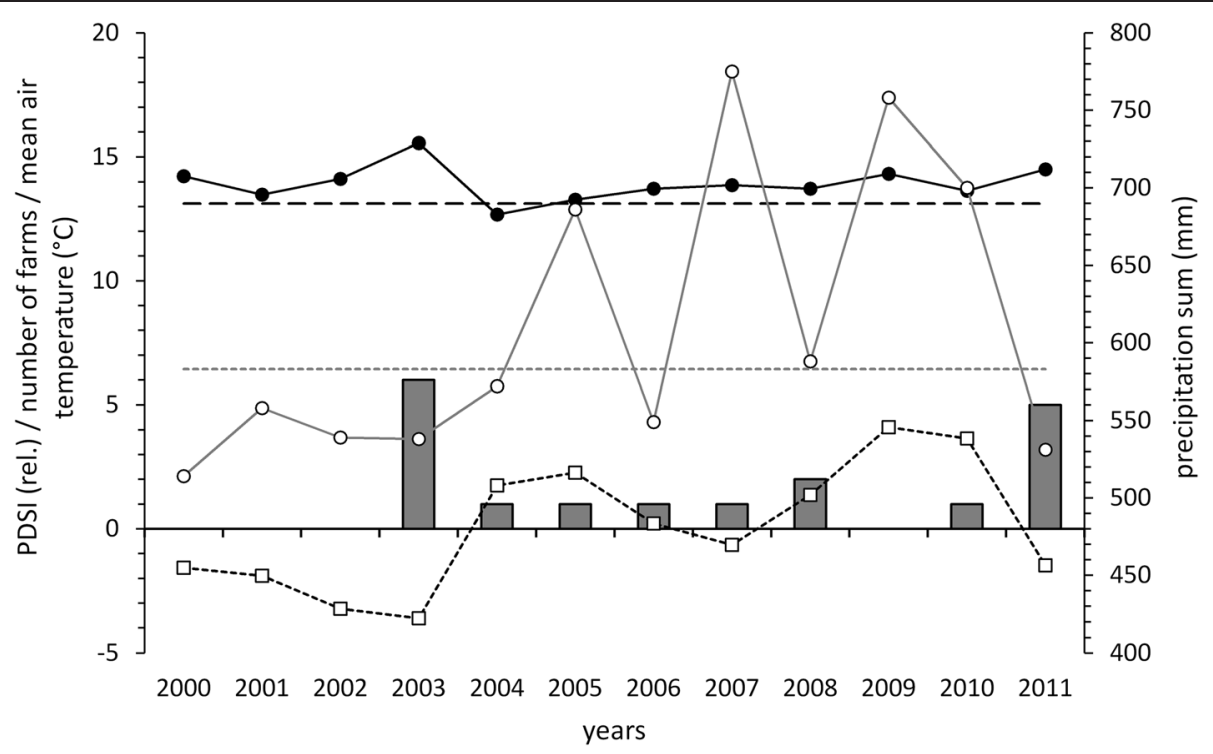

Figure $\mathbf{2}$ Annual weather conditions and the occurrence of grub damage since $\mathbf{2 0 0 0}$ in region 1. Mean air temperature, mean precipitation sum and mean drought index (PDSI) during adult flight and main larval feeding period (May - September) of Phyllopertha horticola (Scarabaeidae),

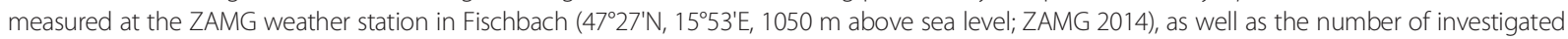
farms in sampling region 1 (near Fischbach, 9 farms in total) that reported grub damages in the respective year (grey bars); solid black line with black circles = annual mean air temperatures, solid grey line with white circles = annual precipitation sums, dashed black line = mean air temperature from 1971 to 2000 (May - September), dotted grey line = mean precipitation sum from 1971 to 2000 (May - September), dotted black line with white squares $=$ annual Palmer Drought Severity Index (PDSI), ranging from $+5=$ extreme wetness to $-5=$ extreme drought.

five evenly distributed soil samples $(0-10 \mathrm{~cm})$ per site. The soils were analyzed by Bio Forschung Austria for the contents of humus (\%), $\mathrm{N}_{\min }(\mathrm{kg} / \mathrm{ha})$, and dissolved organic carbon (DOC, $\mathrm{kg} / \mathrm{ha}$ ) as well as the $\mathrm{pH}-\mathrm{H}_{2} \mathrm{O}$. Further soil characteristics were obtained from the eBOD database (http://gis.lebensministerium.at/eBOD): maximum depth of the A-horizon $(\mathrm{cm})$, humus content eBOD (\%; derived by the IKT Petzenkirchen) and water supply (= estimated values: 1 = very low to 7 = very high). Topographical data were derived from the Styrian GIS system (www.gis.steiermark.at): altitude ( $m$ above sea level), slope (degrees) and aspect (degrees). The soil texture (percentage of sand, silt and clay) of the soil samples was analysed by the IKT-Petzenkirchen (A-3252 Petzenkirchen). Furthermore, the management regime and the detailed damage history of each site was recorded by interrogating the respective farmers: the usual numbers of cuts and grazings and the usual amount of applied manure $(0=$ none, 1 = low, 2 = medium, 3 = high) per year.

\section{Statistics}

The data were statistically analyzed using SPSS 11.5.1 (SPSS Inc., Chicago, IL, USA). An error probability of $\mathrm{p} \leq 0.05$ was considered as statistically significant, $0.05<$ $\mathrm{p} \leq 0.1$ was considered as trend and $0.1<\mathrm{p} \leq 0.15$ as weak trend. For each sampling site, the grub numbers per subsample and species were averaged. To assess the accuracy of the estimated mean grub densities per site, the confidence intervals $(95 \%, \mathrm{p}=0.05)$ were calculated.

Differences between damaged and undamaged sites considered grub density (= all species) and P. horticola density, environmental and management variables were analyzed by t-tests or by Mann-Whitney-U-tests, in case of nonparametric data.

Relationships between $P$. horticola density and management, as well as environmental variables, were modeled and tested by a stepwise multiple linear regression analysis. Additionally, Pearson correlation analyses and, in case of non-parametric data, Spearman rank correlation analyses were conducted. The probability of grub damage, i.e. the probability that a site belonged to the category that had been recently damaged by grubs (= high risk) as reported by the farmers, was modeled by a stepwise multiple logistic regression analysis in dependence of management and environment.

To investigate the influence of grub feeding activity on the humus content of the soil, the relationship between the humus contents in the soil samples and the corresponding eBOD humus contents, which had been derived from a soil map and were therefore unaffected by grub densities, was modeled by a linear regression analysis. In a second step, the effect of grub feeding on this relationship was evaluated by testing the explanatory contribution of the parameter "grub density per $\mathrm{m}^{2}$ " (all species), when added to the linear regression model. 
Table 2 Localisation of the sampling sites and collected data on grub densities and damage; years = years from 2000 to 2010 in which damage was observed by the farmers

\begin{tabular}{|c|c|c|c|c|c|c|c|c|c|c|c|c|c|}
\hline \multirow[b]{2}{*}{ Sample } & \multirow[b]{2}{*}{ Region } & \multirow[b]{2}{*}{ Farm } & \multirow[b]{2}{*}{ Field } & \multirow[b]{2}{*}{ Sampling date } & \multicolumn{2}{|c|}{ Coordinates (UTM 33 N, WGS84) } & \multicolumn{3}{|c|}{ Grub damage } & \multirow[b]{2}{*}{ grubs $/ m^{2}$} & \multicolumn{3}{|c|}{ Grubs per species $/ \mathrm{m}^{2}$} \\
\hline & & & & & Easting & Northing & Before 2011 & Years & In 2011 & & P. horticola & H. philantus & Melolontha sp. \\
\hline 11 & 1 & 1 & 1 & 2011-09-06 & 548047 & 5254667 & yes & 2003,2010 & yes & 113.2 & 113.2 & 0.0 & 0.0 \\
\hline 12 & 1 & 1 & 2 & 2011-09-06 & 548141 & 5254924 & no & / & no & 71.9 & 71.9 & 0.0 & 0.0 \\
\hline 21 & 1 & 2 & 1 & 2011-09-06 & 548602 & 5256315 & yes & 2003,2006 & yes & 205.2 & 204.2 & 0.0 & 1.0 \\
\hline 22 & 1 & 2 & 2 & 2011-09-06 & 548678 & 5256179 & no & / & no & 4.2 & 4.2 & 0.0 & 0.0 \\
\hline 31 & 1 & 3 & 1 & 2011-09-07 & 560089 & 5258184 & no & / & no & 37.5 & 37.5 & 0.0 & 0.0 \\
\hline 32 & 1 & 3 & 2 & 2011-09-07 & 559905 & 5258072 & yes & 2003 & yes & 303.1 & 303.1 & 0.0 & 0.0 \\
\hline 41 & 1 & 4 & 1 & 2011-09-14 & 556813 & 5256383 & yes & 2003 & no & 33.3 & 33.3 & 0.0 & 0.0 \\
\hline 42 & 1 & 4 & 2 & 2011-09-14 & 556829 & 5256594 & no & / & no & 1.0 & 1.0 & 0.0 & 0.0 \\
\hline 51 & 1 & 5 & 1 & 2011-09-23 & 556937 & 5257877 & yes & 2007,2008 & no & 60.4 & 60.4 & 0.0 & 0.0 \\
\hline 52 & 1 & 5 & 2 & $2011-09-23$ & 556903 & 5258062 & no & / & no & 50.0 & 50.0 & 0.0 & 0.0 \\
\hline 61 & 1 & 6 & 1 & 2011-09-22 & 560243 & 5257713 & no & / & no & 1.0 & 1.0 & 0.0 & 0.0 \\
\hline 62 & 1 & 6 & 2 & $2011-09-22$ & 560385 & 5256908 & yes & 2003,2004 & yes & 94.8 & 94.8 & 0.0 & 0.0 \\
\hline 71 & 1 & 7 & 1 & 2011-09-28 & 554443 & 5257666 & no & / & no & 3.1 & 3.1 & 0.0 & 0.0 \\
\hline 72 & 1 & 7 & 2 & 2011-09-28 & 554287 & 5257875 & yes & 2008 & no & 71.9 & 71.9 & 0.0 & 0.0 \\
\hline 81 & 1 & 8 & 1 & 2011-09-27 & 556555 & 5259566 & yes & 2003 & no & 26.0 & 26.0 & 0.0 & 0.0 \\
\hline 82 & 1 & 8 & 2 & 2011-09-27 & 556601 & 5259399 & no & / & no & 13.5 & 13.5 & 0.0 & 0.0 \\
\hline 91 & 1 & 9 & 1 & 2011-10-03 & 554569 & 5259652 & yes & 2005 & yes & 97.9 & 97.9 & 0.0 & 0.0 \\
\hline 92 & 1 & 9 & 2 & 2011-10-03 & 554398 & 5259694 & no & / & no & 95.8 & 78.1 & 17.7 & 0.0 \\
\hline 101 & 2 & 10 & 1 & 2011-10-04 & 462434 & 5234317 & yes & $\mathrm{n} / \mathrm{a}$ & yes & 167.7 & 167.7 & 0.0 & 0.0 \\
\hline 102 & 2 & 10 & 2 & 2011-10-04 & 462773 & 5234718 & no & / & no & 30.2 & 30.2 & 0.0 & 0.0 \\
\hline
\end{tabular}




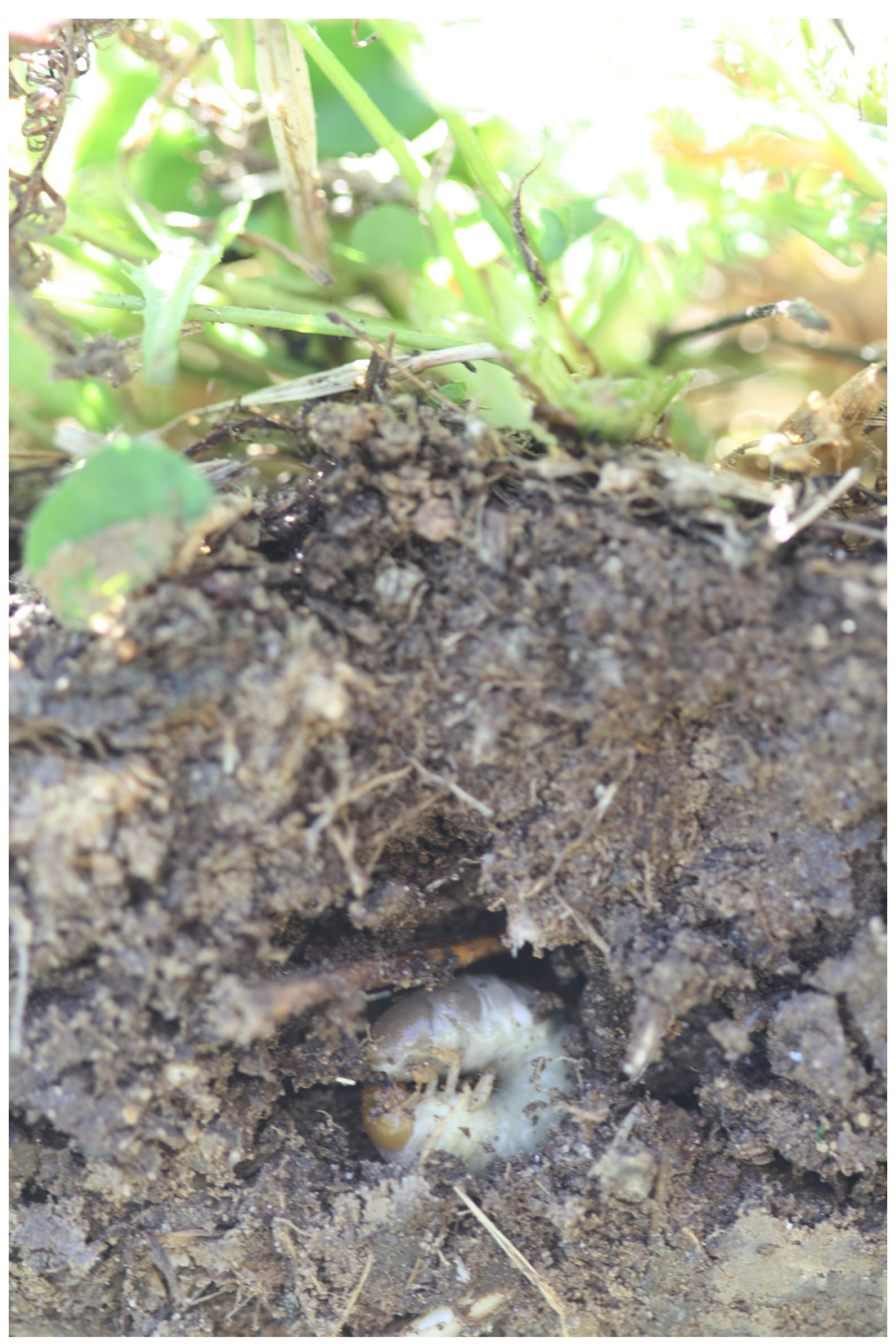

Figure 3 Phyllopertha horticola (Scarabaeidae) larva in situ.

Normal distribution was tested by the KolmogorovSmirnov-Test. If necessary, data were transformed by natural logarithm $(\ln (\mathrm{x}))$, square root $\left(\mathrm{x}^{2}\right)$, division $\left(1 /\left(\mathrm{x}^{*}-1\right)\right)$ or, in case of percentages, by arcussinus $(\operatorname{arsin} \sqrt{ }(x / 100))$, to meet statistical requirements.

In order to depict annual drought conditions in region 1 (ZAMG station Fischbach, see Table 1), we calculated the monthly Palmer Drought Severity Index (PDSI), using historical climate data from 1990 to 2012. The PDSI ranges from extreme wetness (index value: +5 ) to extreme drought (index value: -5 ; Palmer 1965, Dai et al. 2004). For each year, the index was averaged over the adult flight and main larval feeding period of $P$. horticola from May to September (Milne 1959).

\section{Results}

In 2003 and in the sampling year 2011, high proportions of the investigated farms in the region around Fischbach (region 1) were affected by grub damage (2003: 67\% of all investigated farms, 9 farms in total; 2011: 56\%, Figure 2). Both years were characterized by comparatively high mean temperatures and low precipitation sums during the adult flight and main larval feeding period of $P$. horticola (May - September). Accordingly, in both years the Palmer Drought Severity Index value was lower than zero, indicating drought conditions. The years before both $P$. horticola outbreaks showed high mean temperatures as well, whereas their precipitation sums were diverging with low values in 2001 and 2002 but high 
values in 2009 and 2010. Mean temperatures in the region were almost continuously higher than the long term average from 1971 to 2000, with only one exception in 2004.

\section{Differences between damaged and undamaged sites concerning grub density, environmental variables and management}

As shown in Figure 4, a wide range of grub densities was sampled, ranging from 1 to 303 individuals $/ \mathrm{m}^{2}$. Since the confidence intervals indicated a high accuracy of the mean grub densities per site, meaningful site comparisons could be expected. The sites, that had recently shown visible grub damage (dark grey) mainly tended to higher grub densities than the respective sites without noticeable damage (white). A $t$-test calculated across all farms confirmed the difference between the two site categories to be highly significant $(\mathrm{p}=0.002)$. However, at some individual farms $(1,5,8,9)$ the differences were not significant. The collected grubs were largely determined as the garden chafer (P. horticola $=99 \%$ of 1,422 collected individuals in total). The grub density threshold, above which grub damage in the sward was visible in late summer and early autumn 2011 , lay at about 94 grubs $/ \mathrm{m}^{2}$. The only site with a higher mean grub density that showed no damage was the "undamaged" site at farm 9 (= site 92, white bar). This was the only site, at which a significant part of the grubs was not determined as $P$. horticola but as Hoplia philantus. Visible grub damage was recorded in 2011 only at sites that had already been damaged by grubs before our study (= damaged sites). Comparing the two site categories based on management and environmental variables showed that the usual number of cuts was significantly higher at the undamaged than at the damaged sites (Table 3). Cutting frequency was significantly positively correlated with the usual amount of applied manure $(\mathrm{r}=0.51, \mathrm{p}=0.023$; Table 4$)$ and significantly negatively correlated with the usual number of grazings $(p=-0.56, p=0.010)$. However, neither of these variables (amount of applied manure, number of grazings) showed significant differences between damaged and undamaged sites. On the contrary, the DOC contents were significantly higher at the damaged than at the undamaged sites. Humus content tended to have a similar result with a higher mean value for the damaged sites. No other measured variable showed differences. DOC and humus contents were weakly, but significantly positively correlated $(\mathrm{r}=0.49, \mathrm{p}=0.030)$.

\section{Relationship between $P$. horticola grub density, management and environmental variables}

There was no correlation between $P$. horticola grub density and management variables (Table 4). From the environmental variables, only humus content was significantly correlated to the larval distribution of the species, showing a positive relationship $(\mathrm{r}=0.461, \mathrm{p}=0.041)$.

The stepwise multiple linear regression analysis resulted in a model, consisting of two environmental variables,

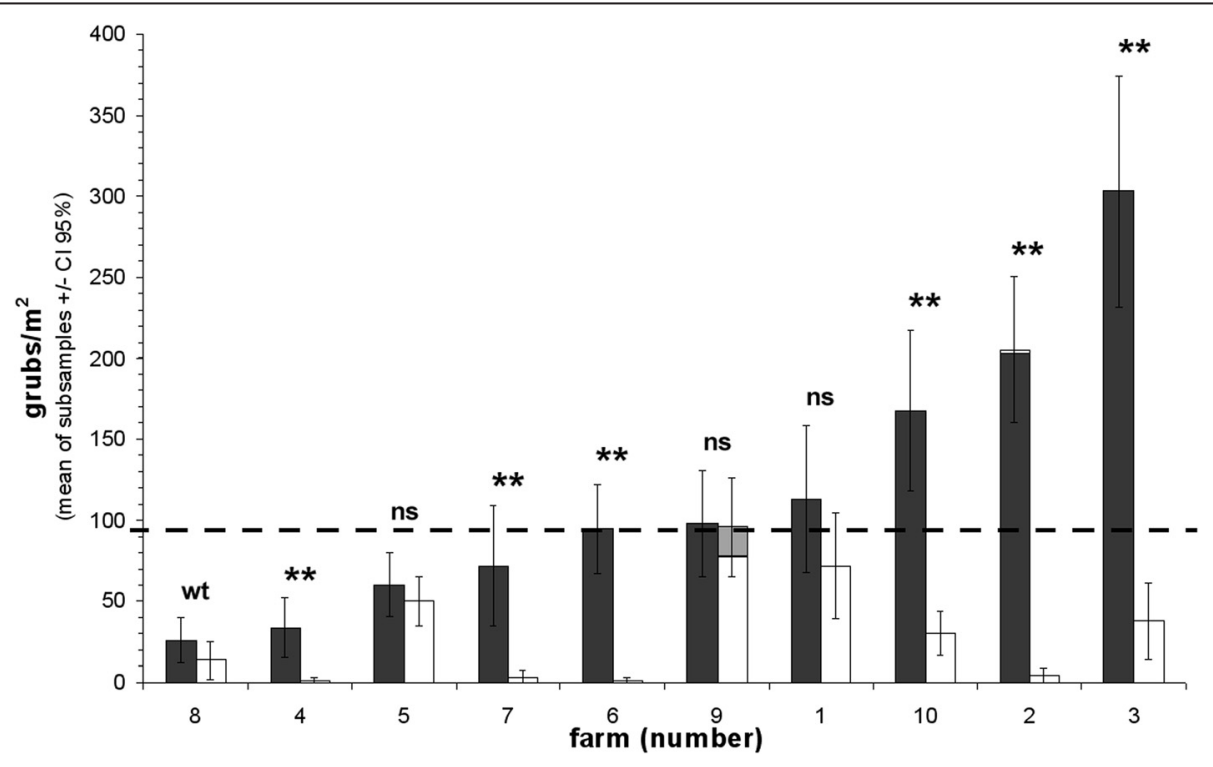

Figure 4 Total mean grub densities per sampling site $(+/-$ confidence interval, $\mathbf{p}=0.05)$. dark bars $=$ sites had recently been affected by grub damage (damaged sites), white bars = grub damage had never been observed by the farmers (undamaged sites); species composition was dominated by Phyllopertha horticola except: light grey section in the white farm 9 bar = mean number of Hoplia philanthus, white section at the top of the dark farm 2 bar = mean number of Melolontha sp.; Statistical symbols according to t-tests and Mann-Whitney- $U$ tests, in case of non-parametric data: ${ }^{* *} p \leq 0.01, w t=$ weak trend $=0.1<p \leq 0.15, \mathrm{~ns}=$ non-significant; The dashed line marks the grub density level, above which grub damages were visible in 2011. 
Table 3 Comparison of the "undamaged" and the "damaged" sites regarding grub density, environment and management; site categories: "undamaged site" = grub damage had never been observed by the farmers (low risk) and "damaged sites" = grub damage had recently occurred (high risk)

\begin{tabular}{|c|c|c|c|c|c|c|c|c|}
\hline \multirow[t]{2}{*}{ Site categories } & \multirow[b]{2}{*}{ Minimum } & \multicolumn{3}{|c|}{ Undamaged sites (= low risk) } & \multirow[b]{2}{*}{ Minimum } & \multicolumn{3}{|c|}{ Damaged sites (= high risk) } \\
\hline & & Maximum & Mean/median & $+/-$ SEM & & Maximum & Mean/median & $+/-$ SEM \\
\hline Grubs (all species) per $\mathrm{m}^{2 * *}$ & 1.04 & 95.83 & 30.83 & 10.47 & 26.04 & 303.13 & 117.63 & 27.16 \\
\hline Grub damages 2011 (ord) & 0 & 0 & 0 & / & 0 & 1 & 1 & / \\
\hline Humus (\%) t & 4.57 & 11.95 & 8.13 & 0.72 & 5.89 & 12.53 & 9.93 & 0.67 \\
\hline $\mathrm{N}_{\min }(\mathrm{kg} / \mathrm{ha})$ & 5.00 & 36.00 & 11.90 & 2.81 & 7.00 & 24.00 & 13.20 & 1.50 \\
\hline DOC $(\mathrm{kg} / \mathrm{ha})^{*}$ & 48.00 & 238.00 & 102.80 & 17.07 & 86.00 & 273.00 & 154.20 & 21.96 \\
\hline $\mathrm{pH}-\mathrm{H}_{2} \mathrm{O}$ & 5.16 & 6.13 & 5.53 & 0.10 & 5.15 & 5.75 & 5.49 & 0.06 \\
\hline Clay (\%) & 13.08 & 21.10 & 15.94 & 0.74 & 11.90 & 22.83 & 16.44 & 1.03 \\
\hline Silt (\%) & 29.60 & 42.58 & 34.39 & 1.27 & 27.95 & 38.31 & 33.15 & 1.00 \\
\hline sand (\%) & 41.06 & 57.26 & 49.65 & 1.81 & 38.86 & 56.78 & 50.39 & 1.75 \\
\hline A-horizon max. $(\mathrm{cm})$ eBOD & 20.00 & 30.00 & 24 & 1.25 & 15.00 & 30.00 & 24 & 2.21 \\
\hline Humus db (\%) eBOD & 2.20 & 4.90 & 3.34 & 0.31 & 2.20 & 5.10 & 3.79 & 0.35 \\
\hline Water supply (ord) eBOD & 3.00 & 7.00 & 5 & / & 3.00 & 5.00 & 5 & / \\
\hline Altitude above sealevel (m) & 838.86 & 1103.99 & 983.68 & 25.68 & 850.93 & 1094.65 & 966.47 & 24.67 \\
\hline Slope (degrees) & 4.92 & 22.24 & 13.03 & 1.71 & 3.07 & 24.13 & 14.53 & 1.85 \\
\hline Aspect (degrees) & 3.19 & 169.62 & 66.55 & 15.21 & 2.32 & 147.28 & 74.86 & 17.01 \\
\hline Usual number of cuts/year* & 1.00 & 4.00 & 2.10 & 0.23 & 0.00 & 2.00 & 1.40 & 0.22 \\
\hline Usual number of grazings/year & 0.00 & 2.00 & 1.00 & 0.15 & 1.00 & 4.00 & 1.60 & 0.40 \\
\hline Usual manure amount/year (ord) & 1.00 & 3.00 & 1.5 & / & 0.00 & 3.00 & 1 & / \\
\hline
\end{tabular}

For parametric data the means (+/-SEM $=$ standard error of the mean), in case of ordinal parameters (ord) the medians were calculated. Significant differences between the two site categories are indicated by: ${ }^{* *}=p \leq 0.01,{ }^{*}=0.05 \geq p>0.01, t=0.1 \geq p>0.05$ trend. The $p$-values were calculated by t-tests or Mann Whitney U-tests in case of ordinal variables. Parameters: The soil parameters were analysed from soil samples $(0-10 \mathrm{~cm})$, except the parameters marked by "eBOD" which were read from a soil database (eBOD, 2013); "DOC" = dissolved organic carbon, "A-horizon max". = maximum depth of the A-horizon, "water supply" (1 = very low to $7=$ very high), "aspect" = deviation from facing south (180 degrees), "usual manure amount / year" ( $0=$ no to $3=$ much).

explaining 38\% of the P. horticola density variance (Figure 5). The higher the humus content (in $0-10 \mathrm{~cm}$ soil depth) and the deeper the A-horizon, the more P. horticola larvae were found. As shown in Figure 5, the sites deviating positively from the dashed line (= linear regression between humus content and $P$. horticola density) had a deeper A-horizon (= larger circles) than the sites deviating negatively.

The humus contents in the soil samples were constantly higher than the humus contents, derived from the eBOD soil map for the respective site (eBOD, 2013; mean difference $=5.46 \pm 2.1 \%$ ). However, both variables showed a weakly positive, significant relationship (Figure 6). Grub density (= number of grubs per $\mathrm{m}^{2}$, all species) provided no additional information for explaining the humus content in the soil samples ( $\mathrm{p}$ for grubs $/ \mathrm{m}^{2}=0.140$, when added to the regression model). As shown in Figure 6, the small circles (= sites with grub densities $\leq 50 \mathrm{grubs} / \mathrm{m}^{2}$ ) and the large circles (= grub densities $>50$ grubs $/ \mathrm{m}^{2}$ ) scattered comparably around the dashed linear regression line. Similarly to the humus contents in the soil samples, the eBOD humus contents weakly tended to a positive correlation with grub density $(\mathrm{r}=0.366, \mathrm{p}=0.112)$.
Probability of grub damage in response to environmental and management conditions

According to the stepwise multiple logistic regression analysis, the probability that a site belonged to the category that had been recently damaged by grubs (= damaged sites = high risk) was dependent from the humus content in the soil $(0-10 \mathrm{~cm})$ and the number of cuts per year (Figure 7). The higher the humus content in soil and the lower the usual cutting frequency, the higher the probability of damage was. On basis of this model, $85 \%$ of the sites could be correctly classified as recently damaged (= high risk) and undamaged (= low risk) sites, when defining 50\% probability as decision limit. As shown in Figure 7, only two recently damaged sites (= dark grey circles) had less than $50 \%$ probability (dashed line) and only one undamaged site ( $=$ white circles) had more than $50 \%$ probability to belong to the high risk category.

\section{Discussion}

Our study provides systematically collected information on grub densities and the dominant grub species at damaged and undamaged mountainous grassland sites in eastern Austria. Additionally, the results contribute to 
Table 4 Correlation matrix between grub density (all species), Phyllopertha horticola density and environmental and management variables Grub density P. horticola Humus $\mathrm{N}_{\min } \mathrm{DOC} \quad \mathrm{pH}-\mathrm{H}_{2} \mathrm{O}$ Clay Silt Sand A-horizon Humus Water Altitude Slope Aspect Cuts Grazings Manure

\begin{tabular}{|c|c|c|c|c|c|c|c|c|c|c|c|c|c|c|c|c|c|c|}
\hline Grub density & 1 & & & & & & & & & & & & & & & & & \\
\hline P. horticola & $1.00 * *$ & 1 & & & & & & & & & & & & & & & & \\
\hline Humus & $0.46^{*}$ & $0.46^{*}$ & 1 & & & & & & & & & & & & & & & \\
\hline$N_{\min }$ & 0.36 & 0.36 & $0.55^{*}$ & 1 & & & & & & & & & & & & & & \\
\hline DOC & 0.29 & 0.30 & $0.49^{*}$ & 0.13 & 1 & & & & & & & & & & & & & \\
\hline $\mathrm{pH}-\mathrm{H}_{2} \mathrm{O}$ & -0.17 & -0.15 & $0.40 t$ & 0.23 & -0.11 & 1 & & & & & & & & & & & & \\
\hline Clay & -0.14 & -0.13 & 0.27 & -0.23 & 0.14 & 0.16 & 1 & & & & & & & & & & & \\
\hline Silt & -0.31 & -0.30 & 0.25 & 0.04 & -0.17 & 0.27 & $0.50^{*}$ & 1 & & & & & & & & & & \\
\hline Sand & 0.27 & 0.26 & -0.29 & 0.09 & 0.04 & -0.25 & $-0.83^{* *}$ & $-0.90^{* *}$ & 1 & & & & & & & & & \\
\hline A-horizon & 0.37 & 0.37 & -0.23 & -0.09 & $-0.45^{*}$ & -0.07 & $-0.50^{*}$ & -0.27 & 0.43 & 1 & & & & & & & & \\
\hline Humus eBOD & 0.37 & 0.36 & $0.45^{*}$ & $0.49^{*}$ & 0.07 & 0.16 & -0.02 & 0.42 & -0.26 & 0.10 & 1 & & & & & & & \\
\hline Water supply & -0.04 & -0.05 & 0.13 & -0.13 & 0.01 & -0.20 & 0.13 & 0.11 & -0.12 & -0.21 & 0.29 & 1 & & & & & & \\
\hline Altitude & -0.06 & -0.05 & 0.14 & -0.14 & 0.01 & $0.48^{*}$ & 0.24 & 0.01 & -0.11 & 0.07 & -0.01 & -0.17 & 1 & & & & & \\
\hline Slope & 0.08 & 0.06 & 0.17 & 0.10 & 0.22 & 0.20 & 0.25 & -0.00 & -0.12 & -0.20 & 0.06 & 0.10 & 0.22 & 1 & & & & \\
\hline Aspect & -0.09 & -0.09 & -0.31 & 0.02 & -0.06 & $-0.59^{*}$ & 0.90 & 0.06 & -0.09 & 0.05 & -0.15 & 0.01 & -0.26 & -0.17 & 1 & & & \\
\hline Cuts & -0.06 & -0.08 & 0.03 & 0.02 & -0.36 & 0.13 & -0.06 & 0.05 & -0.01 & 0.07 & 0.15 & 0.16 & 0.07 & -0.31 & -0.25 & 1 & & \\
\hline Grazings & 0.09 & 0.09 & -0.06 & -0.31 & $0.50 *$ & -0.34 & 0.12 & 0.10 & -0.09 & -0.05 & -0.10 & 0.07 & 0.01 & $0.47^{*}$ & 0.14 & $-0.56^{*}$ & 1 & \\
\hline Manure amount & -0.22 & -0.23 & 0.03 & 0.13 & -0.37 & $0.53^{*}$ & -0.01 & -0.05 & 0.03 & 0.08 & 0.02 & -0.24 & 0.26 & -0.37 & $-0.55^{*}$ & $0.51^{*}$ & $-0.61^{* *}$ & 1 \\
\hline
\end{tabular}

The correlation coefficients were calculated across all sites according to Pearson or Spearman in case of the variables "water supply", "cuts" = usual number of cuts per year, "grazings" = usual number of grazings per year and usual "manure amount" per year. Significant coefficients are marked: ${ }^{*}=0.05 \geq p>0.01{ }^{* *}=p \leq 0.01$. For the definition of parameters see Table 3 . 


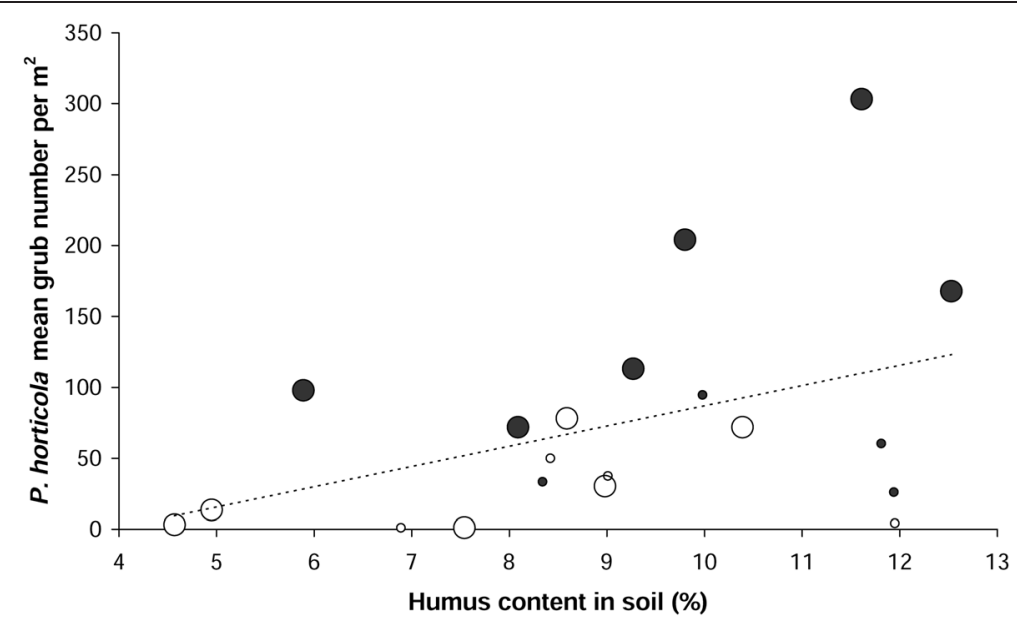

Figure 5 The relationship between measured humus content, soil depth and $P$. horticola density. $x$-axis: humus content in soil samples (\%; 0 - $10 \mathrm{~cm}$ soil depth), $y$-axis: P. horticola mean grub number per $\mathrm{m}^{2}$, size of circles: maximum depth of A-horizon ( $\mathrm{small}=15-20 \mathrm{~cm}$, large $=25-30 \mathrm{~cm}$ ); $R^{2}$ corr. $=0.38, p=0.006$ according to a multiple linear regression; dashed line $=$ linear regression of $P$. horticola grub density on humus content in the soil; color of circles: white = grub damage had never been observed by the farmers (undamaged sites), dark $=$ sites had recently been affected by grub damage (damaged sites).

understanding the site and management characteristics that favor high grub densities and the resulting grub damage.

Comparing grub damage histories recorded at the investigated sites with corresponding weather data indicated that grub damage is promoted by drought conditions in the growing season (May to September), resulting from high mean temperatures and comparatively low precipitation sums. This outcome supports several reports in the literature. Studies by Laughlin $(1957 a, 1964)$ have shown that high annual mean temperatures promote the development of $P$. horticola larvae and improve the survival prospects of the pupae. Apart from temperature, also proper soil moisture has shown to be important for $P$. horticola grubs (Milne 1964), though exact limits have not been specified yet. Grünbacher et al. (2007) already found that from 2000 to 2006, the heaviest grub damage occurred in the year of heat and drought 2003. By studying meteorological data, it became obvious that the damaged areas in this year were mainly situated in regions

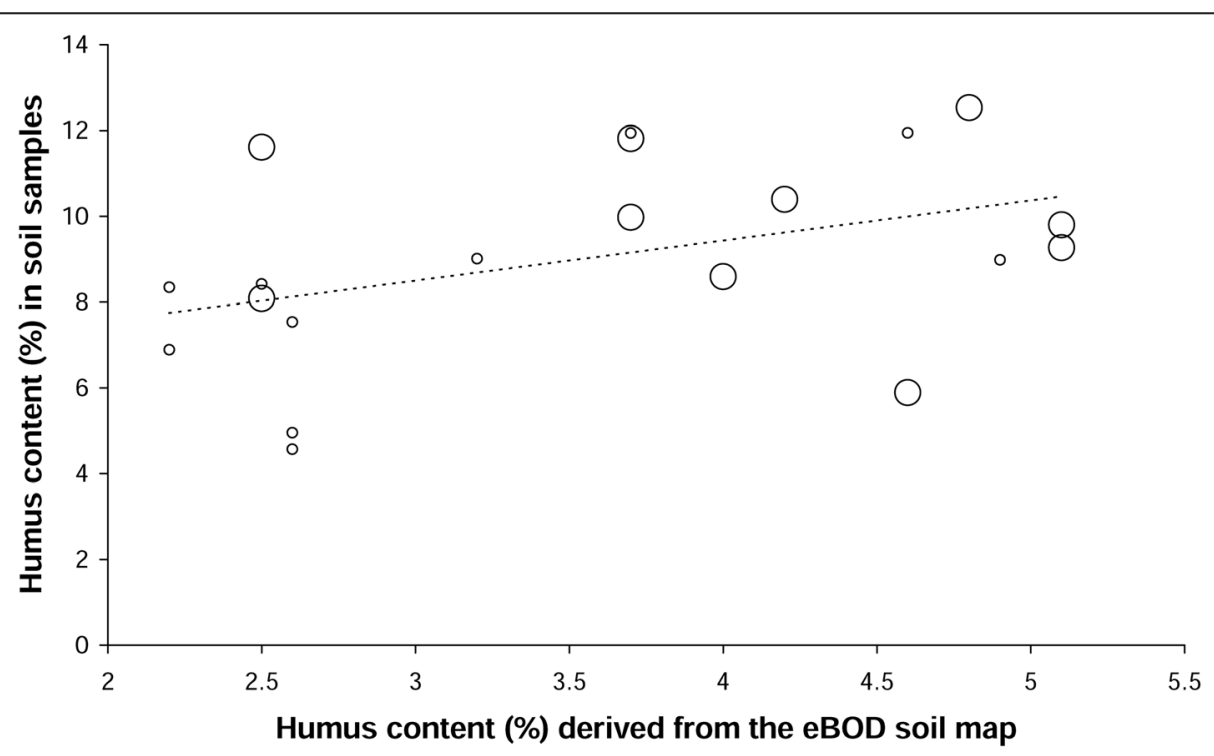

Figure 6 The effect of grub feeding on the measured humus contents. Scatter plot showing the relationship between the humus content, derived from the eBOD soil map, and the humus content in the soil samples; small circles: sites with grub densities $\leq 50$ individuals $/ \mathrm{m}^{2}$ (all species), large circles: sites with grub densities $>50$ individuals $/ \mathrm{m}^{2}$; dashed line $=$ regression line for the two humus variables, $R^{2}$ corr. $=0.16, p=0.046$. 


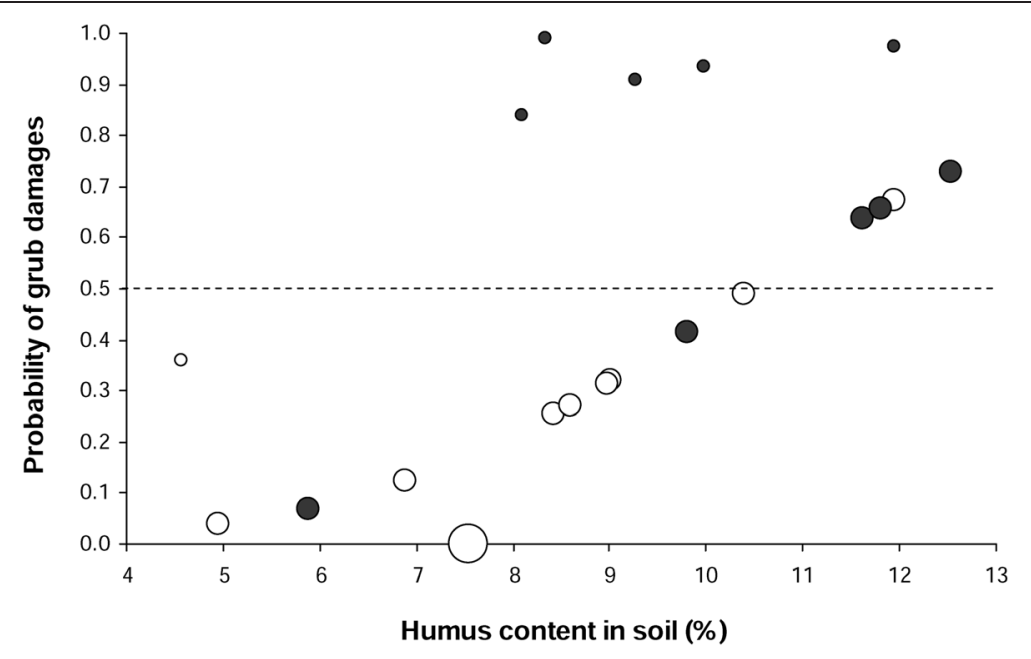

Figure 7 The relationship between humus content, cutting frequency and grub damage. $x$-axis: humus content in soil samples $(\%, 0-10 \mathrm{~cm}$ soil depth), $y$-axis: the probability of grub damage calculated by a multiple logistic regression analysis, size of circles: the usual number of cuts per year ( mall = $0-1$ cut, medium =2, large =4); color of circles: white = grub damage had never been observed by the farmers - low risk (undamaged sites), dark = sites had recently been affected by grub damage - high risk (damaged site); dashed line $=50 \%$ probability that a site belongs to the high risk category.

with a strong precipitation deficit from January to August 2003 compared to average precipitation sums for this period (Hann et al. 2008). Drought can additionally intensify the effects of grub feeding to the sward by accelerating its withering and delaying its regeneration (Grünbacher et al. 2007). Rising temperatures and intensified drought in the course of climate change as shown in Figure 2 might be responsible for increasingly common grub damages over the past decades in region 1 , as reported by the farmers.

$P$. horticola was the most frequent species at the sampling sites (99\% of all collected grubs). The rather shallow sampling depth of $10 \mathrm{~cm}$ allowed more samples per site, but could have biased the outcome to some degree. First, other grub pest species than $P$. horticola might tend to deeper soil layers, especially when the top soil is occupied by $P$. horticola larvae. Second, the third larval instar of M. melolontha starts pupating in deeper soil layers approximately at the end of June (Pötsch et al. 1997, Albert and Fröschle 2010, Kahrer et al. 2011). These grubs would have been missed in the grub survey from September to early October. However, no main flight year of $M$. melolontha was to be expected for the following year 2012 in the investigated regions (Faber 1961, Kahrer et al. 2011). Accordingly, the proportion of third instar larvae in 2011 would have been rather low. Third, under drought stress grubs might migrate into deeper soil regions with more favorable conditions (Ritterhaus 1927, quoted after Milne 1956, Benker and Leuprecht 2005, Albert and Fröschle 2010). Consequently, the densities of some grub species might be underrepresented in our results. But, if sites would have harbored significant populations of other species than P. horticola, it would have been quite unlikely that all individuals were located strictly below $10 \mathrm{~cm}$ soil depth. According to Keller et al. (2008) grub damage is usually caused by a single species. Therefore, we conclude that $P$. horticola was the dominant species at all sampling sites. This supports observations reported in the literature that this species is largely responsible for damage in Austrian mountainous grassland, while Melolontha spp. tend to lower altitudes (Pötsch et al. 1997, Traugott 2003, Benker and Leuprecht 2005).

The grub density threshold, above which damage was visible in 2011, lay at 94 grubs $/ \mathrm{m}^{2}$. This result corresponds quite well to the threshold value of $100 \mathrm{P}$. horticola larvae/ $\mathrm{m}^{2}$ recommended for greenkeepers by Bocksch (2003) and Fischer (2007). The highest $P$. horticola grub density in our study was 303 individuals $/ \mathrm{m}^{2}$. Also Juen and Traugott (2007) described that $P$. horticola can reach densities $>200$ individuals $/ \mathrm{m}^{2}$. Faber (1951b) reported densities even up to 700 individuals $/ \mathrm{m}^{2}$ during heavy outbreaks. Because of its dominance in our data, regression analyses with environmental and management variables were only conducted for this species. Only at one site in region 1 (Figure 4: farm 9, Table 2), a significant proportion of the collected grubs was determined as Hoplia philanthus. High densities of this species were previously detected in Tyrolean cultivated grassland (Traugott and Juen 2008). The fact that this site was the only site with a higher density than 94 grubs $/ \mathrm{m}^{2}$ in total, but no visible damage in 2011, indicates that $H$. philanthus might be less dangerous for agricultural grassland than $P$. horticola, although Keller and Zimmermann 
(2005) reported an increasing importance of Hoplia spp. in Germany. Ansari et al. (2006) considered the species to be a severe pest in Belgian turf.

In 2011, grub damage was only recorded at sites which had also been damaged in preceding years $(=$ damaged sites, high risk). Whereas, the sites at which the farmers had never observed any grub damage (= undamaged sites, low risk), were not damaged in 2011 as well. This consistency confirmed the farmers' observations on high risk and low risk sites. However, not all high risk sites had grub populations that were strong enough to cause visible feeding damage in 2011. This might reflect the irregular year to year fluctuations of $P$. horticola populations, as shown by Milne (1984). The author described weather conditions, but also enemies (predators, diseases) and intraspecific competition as main factors, responsible for these fluctuations. Even though the population densities are fluctuating, the recently damaged sites had significantly higher grub densities than the undamaged sites, indicating that sites which were classified as high risk sites by the farmers are more suitable habitats for $P$. horticola grub development than low risk sites. Interestingly, at three farms $(1,5,9)$ the undamaged sites also revealed significant grub populations. At these sites, the differences to the corresponding damaged sites were quite weak. Obviously, low risk sites, which never show visible grub damage can harbor high $P$. horticola populations. This fact should be considered, when determining where to conduct grub control measures, e.g. the application of entomopathogenic fungi or nematode products (Pernfuss et al. 2005, Strasser 2010).

Since the low and high risk areas of a farm can be situated quite close, local site specific factors must play an important role for the development of high grub densities and the resulting grub damage risk. High risk sites provide adequate conditions for $P$. horticola to maintain relatively high population densities during unfavorable periods, and to produce outbreaks when the fluctuating factors are in the optimum.

\section{Which site factors are favoring high $P$. horticola grub densities?}

Here, the humus content (= organic carbon) in soil is significantly related to $P$. horticola grub density. In soils with higher humus contents, more grubs $/ \mathrm{m}^{2}$ were found than in soils with lower humus contents. At least, this outcome is valid for the sandy and mostly shallow grounded and sloping sampling sites in this study. The positive correlation corresponds very well to the results of Laznik and Trdan (2014), who also reported a significant relationship between grubs $/ \mathrm{m}^{2}$ and the content of organic matter. In a former study the same authors already measured a high organic matter content (12.4\%) in a Slovenian grassland soil with critical grub densities (Laznik et al. 2012). Raw (1951) found a higher percentage of organic carbon in soils at sites damaged by $P$. horticola larvae than in soils at undamaged sites. The author interpreted the increased organic carbon content at damaged sites as an effect of the grub feeding activity on grass roots. In order to examine this relationship, we compared the humus content in the soil samples with the eBOD humus contents. The latter were derived from a soil map and were therefore unaffected by grub feeding. If grub feeding activity would have been the cause for the increased humus contents at sites with larger grub populations in 2011, the deviations of the soil sample humus contents from the eBOD humus contents would have been connected to the measured grub densities. As shown in Figure 6, the hypothesis of Raw was not supported by our data. On the contrary, the two humus contents even showed a weak positive, but significant correlation and grub density contained no significant information for explaining the residues in this relationship. The deviations between the soil sample and the eBOD humus contents can be attributed to inaccuracies of the soil map, which might not reflect the impact of grassland management on humus content and/ or small scale heterogeneity. Similarly to the humus percentages in the soil samples, the eBOD humus values weakly tended to a positive correlation with grub densities, as well. Hence, high humus contents might actually favor the oviposition of $P$. horticola females and/or the development of the larvae. Faber (1951b) observed that M. melolontha prefers soils with high humus contents for larval development.

High humus contents in soil can have various beneficial effects on P. horticola populations. Milne (1956) concluded from the grassy natural habitat of the species that its main food is grass roots. But McQuillan and Webb (1994) found that the larvae of Adoryphorus couloni (Scarabaeidae), which cause increasing damage in southeastern Australian pastures, can selectively feed on concentrated sources of soil organic matter. Kahrer et al. (2011) state, however without references, that young $M$. melolontha larvae feed on fine roots but also on humus particles, which may be valid for young $P$. horticola larvae as well. According to Li and Brune $(2005,2007)$ humivorous Scarabaeidae larvae can utilize the microbial biomass as well as the nitrogenous components of humus.

Apart from the possible function as food resource for young larvae of $P$. horticola, high humus contents might provide optimal moisture conditions by contributing to the water permeability in soils with higher clay or silt content, but retaining enough soil water in sandy soils (Scheffer et al. 2002), which were typical for the investigated grassland sites. On the one hand, Laughlin (1957b) showed that the eggs are not resistant to desiccation with relative humidities $\leq 98 \%$ being lethal. On the other hand, moist soils are inadequate for $P$. horticola grub development (Milne 1964), because of increased pressure by 
diseases (Milne 1984), difficult hatching conditions (Raw 1951) and the negative effect on soil temperatures. Milne (1964) even considered that:" Apart from proper food, which is provided by grassland, the most important living condition for the garden chafer in the soil appears to be proper soil moisture". Gaylor and Frankie (1979) showed that Phyllophaga crinita (Scarabaeidae), causing heavy damage to crops and turfs in North- and CentralAmerica, did not oviposit in very wet or very dry soil and egg as well as early larval instar survival were low under extreme conditions. Comparably, Cyclocephala immaculata (Scarabaeidae), a pest in north-american turf grasses, failed to oviposit and introduced $1^{\text {st }}$ instar larvae did not survive in desiccated turf (Potter and Gordon 1984).

Additionally, due to the darker color humus rich soils are more susceptible to warming by sun radiation (Scheffer et al. 2002). As grubs are poikilothermic, all soil characteristics affecting soil temperature are potentially important factors for grub development. Scheerpelz (1950) supposed that the temperature radiation of soils might even direct swarming females of $M$. melolontha to adequate sites for oviposition. High humus contents might also promote optimal soil structures for the mobility of the larvae and the adults, which deposit their eggs up to $20 \mathrm{~cm}$ below the soil surface (Milne 1956).

The second factor, significantly connected to grub density was the maximum depth of the A-horizon. The deeper the A-horizon, the more grubs per square meter could be found. Together, humus content and depth of A-horizon explained $38 \%$ of the grub density variation with the highest grub densities in deep humus rich soils. Raw (1951) considered soil depth to affect grub mortality most likely during hibernation in severe winters, but the hypothesis was not supported by his data. Milne (1956) stated that $P$. horticola larvae do "not necessarily hibernate at a deeper level in fields with deeper soil". Apart from the unclear effect on hibernation depth, deeper soils might simply provide a larger habitat with a more productive root sphere.

\section{Which management and environmental variables characterize high risk and low risk sites?}

Sites that had recently shown grub damage (= high risk) had higher grub densities than sites where grub damage had never been observed by the farmers (= low risk). Accordingly, high risk sites can be considered as better habitats for $P$. horticola development and/or as more attractive locations for oviposition than low risk sites.

When calculated across all sampling sites, the high risk sites had significantly higher DOC (Dissolved Organic Carbon) contents and also tended to higher humus contents than the low risk sites. The humus content was directly positively correlated to grub density, which is corresponding to the observation that high risk areas are better grub habitats. The DOC differences might partly be associated with the humus contents. They might also reflect the larger grub populations at the high risk sites, i.e. their feeding activity, as supposed by Raw (1951). However, DOC contents were not significantly related to the grub densities measured in 2011. Furthermore, neither of the two variables (humus, DOC) was correlated with the estimated amounts of applied manure, queried from the farmers.

Apart from the soil characteristics, the cutting frequency, i.e. the usual number of cuts per year, was significantly lower at the high risk than at the low risk sites. A higher cutting frequency is usually associated with higher amounts of applied manure, as also supported by our data $(\mathrm{r}=0.505, \mathrm{p}=0.023)$. Both management measures promote dense swards which might be unattractive for oviposition and might be more resilient to grub feeding than weak swards (Pötsch et al. 1997, Bocksch 2003). Additionally, a dense sward hinders the warming of the soil by sun radiation and therefore reduces soil temperature. The lack of a significant difference between damaged and undamaged sites concerning the manuring regime might be an effect of inaccurate data on the amount of applied manure per sampling site.

A stepwise logistic regression analysis resulted in a model that uses cutting frequency together with the humus content for predicting grub damage risk. The higher the humus content and the lower the cutting frequency, the higher the probability was that a site belonged to the high risk category. As discussed above, high humus contents might favor the development of large grub populations, while higher cutting frequencies promote dense swards that might reduce oviposition and are more resilient to grub feeding.

Even though we considered various environmental and management parameters, the significant relationships with grub density were few and the correlations were weak. This suggests further unknown factors covering the relationship between grub density and the measured or recorded parameters, e.g. irregular fluctuations of grub populations due to predators, diseases or intraspecific competition (Milne 1984, Juen and Traugott 2007, Laznik et al. 2012). Humus content and cutting frequency might both affect grub density via their influence on soil temperature, a factor which is probably highly important for the soil-dwelling grubs (Laughlin 1964, 1957a, Milne 1984). But soil temperature strongly depends from local weather, which might as well confound the relationship between actual grub densities and site characteristics.

In consideration of these results, we recommend future investigations on the relationship between soil temperature, humus content, depth of A-horizon, cutting regime, grub density and grub damage risk. The actual, small scale soil temperatures and moistures at the sampling sites should be measured with soil sensors and samplings should be conducted over several years to cover grub 
population fluctuations. Provided that these relationships are well understood, soil temperature models, like CLIMSOIL (Murer et al. 2011, Schaumberger et al. 2013), might enable weather dependent prognoses of grub damage risks in agricultural grassland. Furthermore, we suggest to expand the investigation to the alpine regions in Upper Austria, Salzburg and Tyrol to cover all areas within Austria where damage by grubs occur frequently or regularly.

\section{Conclusions}

The results of this study indicate that $P$. horticola was the dominant species in the top soil layer of the sampled sites and was largely responsible for grub damage in the investigated region, which was situated at $800-1,200 \mathrm{~m}$ above sea level and characterized by lime-free, sandy Leptosols or Cambisols over siliceous, gravelly material. The damage threshold for P. horticola lay at 94 grubs $/ \mathrm{m}^{2}$. Also sites which had not shown grub damage revealed significant grub populations, which should be considered when applying control measures. Regression analyses indicated high humus contents in soil to be favorable for the development of high grub densities in the sampling sites, while intensive cutting frequencies might have mitigating effects on grub damage.

\section{Competing interests}

The authors declare that they have no competing interests.

\begin{abstract}
Authors' contributions
PH: Contributed to the study design, data collection, analysis and interpretation and compiled the manuscript. CT: Contributed to the study design, data collection and literature review. KW: Contributed to the data collection, literature review and data interpretation. JE: Contributed to the study design, the collection and interpretation of meteorological data, provided guidance and improved the manuscript. BK: Drafted the study design, provided guidance and improved the manuscript. All authors read and approved the final manuscript.
\end{abstract}

\section{Acknowledgements \\ The study was part of the project CLIMSOIL, which was funded by the Austrian Climate and Energy Fund of the Federal State (Austrian Climate Research Program)- managed by the Austrian Research Promotion Agency and Kommunalkredit Public Consulting $\mathrm{GmbH}$. We want to thank the farmers for their cooperation and all project partners, particularly the IKT Petzenkirchen for analyzing the grain size in the soil samples and providing the humus contents from the eBOD soil database.}

\section{Author details \\ 'Bio Forschung Austria, Esslinger Hauptstrasse 132-134, Vienna 1220, Austria. ${ }^{2}$ MELES GmbH, Mörikestraße 20, St. Pölten 3100, Austria. ${ }^{3}$ Department of Water, Atmosphere and Environment, University of Natural Resources and Life Sciences, Vienna 1180, Austria.}

Received: 10 January 2015 Accepted: 5 March 2015 Published online: 24 March 2015

\section{References}

Albert R, Fröschle M (2010) Der Feldmaikäfer und seine Engerlinge - Melolontha melolontha. Merkblatt - Integrierter und biologischer Pflanzenschutz im Obst- und Gartenbau, Landwirtschaftliches Technologiezentrum Augustenberg (LFZ), Karlsruhe
Ansari MA, Casteels H, Tirry L, Moens M (2006) Biology of Hoplia philanthus (Col., Scarabaeidae, Melolonthinae): A New and Severe Pest in Belgian Turf. Environ Entomol 35:1500-1507

Benker U, Leuprecht B (2005) Field experience in the control of common cockchafer in the Bavarian region Spessart. Insect Pathogens and Insect Parasitic Nematodes: Melolontha, IOBC/wprs Bulletin 28:21-24

Bocksch M (2003) Gartenlaubkäfer (Phyllopertha horticola). http://www.rasengesellschaft. de/content/rasenthema/2003/06_2003.pdf. Accessed 27 Feb 2013

Dai A, Trenberth KE, Qian T (2004) A global dataset of Palmer Drought Severity Index for 1870-2002: Relationship with soil moisture and effects of surface warming. J Hydrometeorol 5:1117-1130

eBOD (2013) Digitale Bodenkarte von Österreich. Federal Research and Training Centre for Forests, Natural Hazards and Landscape, http://gis. lebensministerium.at/eBOD. Accessed 5 March 2013

Faber W (1951a) Erfahrungen über Maikäfer-Großbekämpfungsaktionen. - Der Pflanzenarzt, 4, 2. Sondernummer, 3-4

Faber W (1951b) Wie erkennen wir die Engerlinge schädlicher Blatthornkäferarten. Der Pflanzenarzt, 4, 2. Sondernummer, 6-7

Faber W (1961) Ergebnisse zehnjähriger Erhebungen über die Flugjahre des Maikäfers (Melolontha melolontha L. und M. hippocastani F.) in Österreich. Pflanzenschutz Berichte 27:101-146

Fischer R (2007) Schädlingsfibel der wichtigsten tierischen Schädlinge im Golfrasen, Teil 3. Greenkeepers J 1(2007):34-41

Freude H, Harde W, Lohse G, Klausnitzer B (1969) Die Käfer Mitteleuropas, Bd. 8, Teredilia, Heteromera, Lamellicornia. Goecke \& Evers Verlag, Krefeld

Gaylor M, Frankie GW (1979) The relationship of rainfall to adult flight activity; and of soil moisture to oviposition behaviour and egg and first instar survival in Phyllophaga crinita. Environ Entomol 8:591-594

Grünbacher EM, Hann P, Trska C, Kromp B, Formayer H (2007) Auswirkung des Klimawandels auf die Ausbreitung der Engerlingsschäden (Scarabaeidae, Coleoptera) im österreichischen Grünland. Startclim 2006, final report. http://www.austroclim.at/fileadmin/user_upload/reports/StCl06C.pdf. Accessed 17 Feb 2015

Hann P, Grünbacher EM, Trska C, Kromp B (2008) Effects of climate change on the dispersion of white grub damages in the Austrian grassland. In: Šarapatka B, Samsonová P (eds) Bioacademy 2008 - Proceedings, Olomouc, CZ, p 62-65

Hasler T (1986) Abundanz- und Dispersionsdynamik von Melolontha Melolontha $(\mathrm{L})$ in Intensivobstanlagen. Dissertation, ETH Zürich

Jackson TA, Klein MG (2006) Scarabs as pests: a continuing problem. Coleopterists Soc Monograph 5:102-119

Juen A, Traugott M (2007) Revealing species-specific trophic links in soil food webs: molecular identification of scarab predators. Mol Ecol 16:1545-1557

Kahrer A, Perny P, Steyrer G, Hausdorf H (2011) Maikäfer nun auch in Ostösterreich auf dem Vormarsch. Forstschutz aktuell 53:5-10

Keller S (1993) Gibt es eine zweijährige Entwicklung beim Feldmaikäfer Melolontha melolontha L.? Mitteilungen der schweizerischen Entomologischen Gesellschaft 66:243-246

Keller S (2004) Distribution of white grubs in Switzerland and their control. Nachrichtenbl Deut Pflanzenschutzd 56:88-90

Keller S, Zimmermann G (2005) Scarabs and other soil pests in Europe: Situation, perspectives and control strategies. Insect Pathogens and Insect Parasitic Nematodes: Melolontha IOBC/wprs Bulletin 28:9-12

Keller S, Dhoj Y, Schweizer C (2008) The challenge of controlling multispecies white grub associations. Insect Pathogens and Insect Parasitic Nematodes, IOBC/wprs Bulletin 31:251-256

Klausnitzer B (1996) Die Larven der Käfer Mitteleuropas, Bd. 3, Polyphage - Teil 2. Gustav Fischer Verlag, Jena

Laughlin R (1957a) Biology and ecology of the Garden Chafer, Phyllopertha horticola (L.), III. The growth of the larva. Bull Entomol Res 48:127-154

Laughlin R (1957b) Absorption of Water by the egg of the garden chafer Phyllopertha horticola L. J Exp Biol 34:226-236

Laughlin R (1964) Biology and Ecology of the Garden Chafer, Phyllopertha horticola (L.). VIII. Temperature and larval growth. Bull Entomol Res 54:745-759

Laznik Z, Trdan S (2014) Evaluation of different soil parameters and wild boar (Sus scrofa [L.]) grassland damage. Ital J Anim Sci 13(3434):759-765

Laznik Z, Vidrih M, Trdan S (2012) The effect of different entomopathogens on white grubs (Coleoptera: Scarabaeidae) in an organic hay-producing grassland. Archives of Biological Science Belgrade 64:1235-1246

Li X, Brune A (2005) Digestion of microbial biomass, structural polysaccharides, and protein by the humivorous larva of Pachnoda epihippiata (Coleoptera: Scarabaeidae). Soil Biol Biochem 37:107-116 
Li X, Brune A (2007) Transformation and mineralization of soil organic nitrogen by the humivorous larva of Pachnoda ephippiata (Coleoptera: Scarabaeidae). Plant Soil 301:233-244

McQuillan PB, Webb WR (1994) Selective soil organic matter consumption by lavae of Adoryphorus couloni (Burmeister) (Coleoptera: Scarabaeidae). Australian J Entomol 33:49-50

Milne A (1956) Biology and ecology of the Garden Chafer, Phyllopertha horticola (L.), II.-The cycle from egg to adult in the field. Bull Entomol Res 47:23-42

Milne A (1959) Biology and ecology of the Garden Chafer, Phyllopertha horticola (L.), IV. The flight season: introduction, and general aspects. Bull Entomol Res 56:685-699

Milne A (1964) Biology and ecology of the Garden Chafer, Phyllopertha horticola (L.), IX. Spatial Distribution. Bull Entomol Res 54:761-795

Milne A (1984) Fluctuation and natural control of animal population, as exemplified in the garden chafer Phyllopertha horticola (L.). Proceedings of the Royal Society of Edinburgh 82b:145-199

Murer E, Krammer C, Eitzinger J, Grabenweger P (2011) GIS data base and methodology for estimating impacts of climate change on soil temperatures and related risks for Austrian agriculture (CLIMSOIL). IUGG Congress Melbourne, Australia. Earth on the Edge: Science for a Sustainable Planet. http://www.boku.ac.at/climsoil/documents/Poster_CLIMSOIL_Melbourne.pdf. Accessed 26 Aug 2013

Palmer WC (1965) Meteorological Drought. Research Paper No. 45, US Department of Commerce, Weather Bureau, Washington, DC, USA

Pernfuss B, Zelger R, Kron-Morelli R, Strasser H (2005) Control of the garden chafer Phyllopertha horticola with GRANMET-P, a new product made of Metarhizium anisopliae. Insect Pathogens and Insect Parasitic Nematodes: Melolontha, IOBC/wprs Bulletin 28:47-50

Pötsch EM, Strasser H, Berger HK (1997) Was Sie über tierische Schädlinge am Grünland wissen sollten. Der fortschrittliche Landwirt, Sonderbeilage 6:1-9

Potter DA, Gordon FC (1984) Susceptibility of Cyclocephala immaculata (Coleoptera: Scarabaeidae) eggs and immatures to heat and drought in turf grass. Environ Entomol 13:794-799

Raw F (1951) The ecology of the Garden Chafer, Phyllopertha horticola (L.) with preliminary observations on control measures. Bull Entomol Res 42:605-646

Ritterhaus K (1927) Studien zur Morphologie und Biologie von Phyllopertha horticola L. und Anomala aena Geer (Coleopt.). Z Morph Ökol Tiere 8:271-408

Schaumberger A, Schaumberger J, Eitzinger J, Grabenweger P (2013) Räumliche Modellierung von Bodentemperaturdaten für Österreich. 14. Klimatag, April 4-5 2013, BOKU Vienna (CCCA, klima + energiefonds, BOKU). http://www. ccca.ac.at/fileadmin/00_DokumenteHauptmenue/03_Aktivitaeten/Klimatag/ Klimatag2013/Poster_14.Klimatag/P08_Schaumberger.pdf. Accessed 17 Feb 2015

Scheerpelz O (1950) Der Maikäfer. Verl. A, Ziemsen, Wittenberg, Lutherstadt

Scheffer F, Schachtschabel P, Blume HP, Brümmer GW, Schwertmann U, Horn R, Kögel-Knabner I, Stahr K, Auerswald K, Beyer L, Hartmann A, Litz N, Scheinost A, Stanjek H, Welp G, Wilke BM (2002) Lehrbuch der Bodenkunde - 15. Auflage, Spektrum Akademischer Verlag, Heidelberg, Berlin

Scheifinger H, Matulla C, Cate P, Kahrer A, Koch E (2007) CLIMPHEN - "Climate impact on plant and insect phenology in Austria. Project, funded by the Global Change Programme of the Austrian Academy of Sciences, final report. http://hw.oeaw.ac.at/0xc1aa500d_0x00167059.pdf. Accessed 25 Feb 2013

Strasser H (2004a) Biocontrol of important soil-dwelling pests by improving the efficacy of insect pathogenic fungi. Laimburg Journal 1:236-241

Strasser H (2004b) Scarabaeiden in Österreich: Schadensumfang und biologische Bekämpfung. Nachrichtenbl Deut Pflanzenschutzd 56:91-94

Strasser H (2010) Beurteilung der Gartenlaubkäferentwicklung und deren Bekämpfung. http://www.uibk.ac.at/bipesco/consultation/pdf_consultation/ strasser_phyllopertha_kontrolle_de.pdf. Accessed 22 Feb 2013

Traugott M (2003) Soil living pests and soil beneficials: control factors of wireworms and white grubs? Entomologica Austriaca 8:7-9

Traugott $\mathrm{M}$ and Juen A (2008) Die Bedeutung von Vögeln als natürliche Regulatoren von Engerlingen im Grünland. BBK-Projekt-1406, final report. https://www.dafne.at/dafne_plus_homepage/download.php?t=ProjectReportAttachment\&k=1406. Accessed 17 Feb 2015
ZAMG (2014) Zentralanstalt für Meteorologie und Geodynamik, http://www. zamg.ac.at. Accessed 22 Nov 2014

Zweigelt F (1928) Der Maikäfer. Studien zur Biologie und zum Vorkommen im südlichen Mitteleuropa. Monographien zur angewandten Entomologie. Beihefte zur Zeitschrift für angewandte Entomologie, XIII, Band, Nr. 9, Verlag Paul Parey, Berlin

\section{Submit your manuscript to a SpringerOpen ${ }^{\circ}$ journal and benefit from:}

- Convenient online submission

- Rigorous peer review

- Immediate publication on acceptance

- Open access: articles freely available online

- High visibility within the field

- Retaining the copyright to your article

Submit your next manuscript at $>$ springeropen.com 